\title{
BTO 3.1.2.55 Milestone Report - Shortlist of potential sensors to be used to detect refrigerant maldistribution in $\mathrm{HXs}$
}

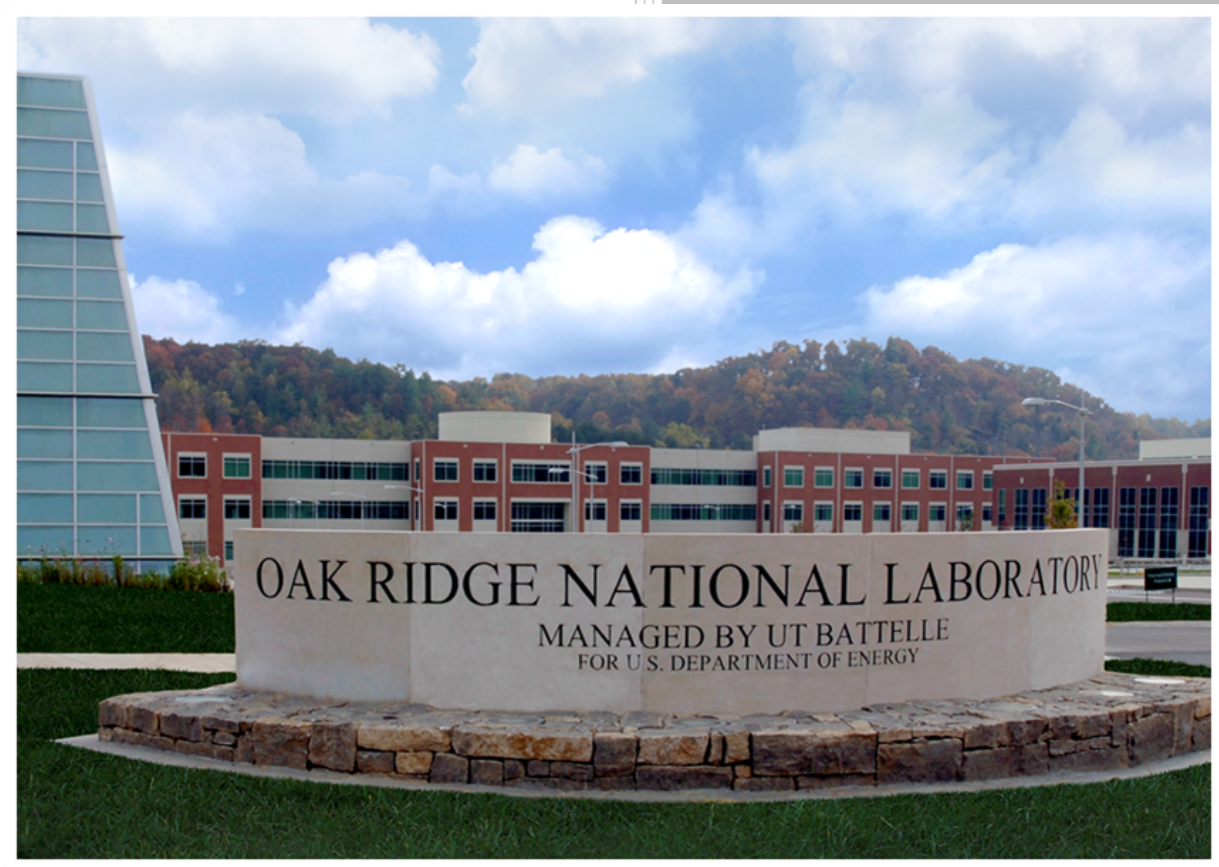

Viral K. Patel Ayyoub Momen Kashif Nawaz Ahmad Abu-Heiba Nathaniel O'Connor Jamal S. Yagoobi

March 31, 2019 


\title{
DOCUMENT AVAILABILITY
}

Reports produced after January 1, 1996, are generally available free via US Department of Energy (DOE) SciTech Connect.

Website www.osti.gov

Reports produced before January 1, 1996, may be purchased by members of the public from the following source:

\author{
National Technical Information Service \\ 5285 Port Royal Road \\ Springfield, VA 22161 \\ Telephone 703-605-6000 (1-800-553-6847) \\ TDD 703-487-4639 \\ Fax 703-605-6900 \\ E-mail info@ntis.gov \\ Website http://classic.ntis.gov/
}

Reports are available to DOE employees, DOE contractors, Energy Technology Data Exchange representatives, and International Nuclear Information System representatives from the following source:

Office of Scientific and Technical Information

PO Box 62

Oak Ridge, TN 37831

Telephone 865-576-8401

Fax 865-576-5728

E-mail reports@osti.gov

Website http://www.osti.gov/contact.html

This report was prepared as an account of work sponsored by an agency of the United States Government. Neither the United States Government nor any agency thereof, nor any of their employees, makes any warranty, express or implied, or assumes any legal liability or responsibility for the accuracy, completeness, or usefulness of any information, apparatus, product, or process disclosed, or represents that its use would not infringe privately owned rights. Reference herein to any specific commercial product, process, or service by trade name, trademark, manufacturer, or otherwise, does not necessarily constitute or imply its endorsement, recommendation, or favoring by the United States Government or any agency thereof. The views and opinions of authors expressed herein do not necessarily state or reflect those of the United States Government or any agency thereof. 
Energy and Transportation Science Division

\title{
BTO 3.1.2.55 MILESTONE REPORT - SHORTLIST OF POTENTIAL SENSORS TO BE USED TO DETECT REFRIGERANT MALDISTRIBUTION IN HXS
}

\author{
Viral K. Patel ${ }^{1}$ \\ Ayyoub Momen ${ }^{1}$ \\ Kashif Nawaz ${ }^{1}$ \\ Ahmad Abu-Heiba ${ }^{1}$ \\ Nathaniel O'Connor ${ }^{2}$ \\ Jamal S. Yagoobi \\ 1: Building Equipment Research Group, ORNL \\ 2: Multi Scale Heat Transfer Laboratory, Worcester Polytechnic Institute, Worcester, MA
}

Date Published: March 31, 2019

Prepared by

OAK RIDGE NATIONAL LABORATORY

Oak Ridge, TN 37831-6283

managed by

UT-BATTELLE, LLC

for the

US DEPARTMENT OF ENERGY

under contract DE-AC05-00OR22725 



\section{SHORTLIST OF SENSORS USED FOR DETECTION OF REFRIGERANT MALDISTRIBUTION}

Table 1 lists the sensors that will be considered for this project to detect refrigerant maldistribution. Along with the measurement method, the table also shows the unique advantages and disadvantages that each sensor has which are relevant to the planned benchtop experimental setup that will be fabricated to study refrigerant maldistribution. The actual setup will likely be fabricated with a combination of the sensors listed.

Table 1. List of sensors used to detect maldistribution

\begin{tabular}{|c|c|c|c|c|}
\hline $\begin{array}{l}\text { Measurement } \\
\text { type }\end{array}$ & Sensor type & Function & Advantages & Disadvantages \\
\hline Flow & Ultrasonic flow sensor (external) & $\begin{array}{l}\text { Measurement of flow } \\
\text { rate in parallel } \\
\text { refrigerant lines in } \\
\text { HX }\end{array}$ & $\begin{array}{l}\text { - Commercially available as a } \\
\text { component } \\
\text { - Inexpensive } \\
\text { - Non-intrusive - can be installed } \\
\text { directly onto microchannel } \\
\text { surface }\end{array}$ & $\begin{array}{l}\text { - Untested - experimental at this } \\
\text { stage } \\
\text { - Relationship between output } \\
\text { signal and actual physical flow is } \\
\text { currently being determined } \\
\text { - Measurement of two-phase flow } \\
\text { unknown }\end{array}$ \\
\hline Flow & Ultrasonic flow sensor (in-line) & $\begin{array}{l}\text { Measurement of flow } \\
\text { rate in parallel } \\
\text { refrigerant lines in } \\
\text { HX }\end{array}$ & $\begin{array}{l}\text { - } \\
\text { - In-line meters do not obstruct } \\
\text { flow }\end{array}$ & $\begin{array}{ll}- & \text { Costly } \\
\text { - } & \text { Intrusive, cannot easily transition } \\
\text { flow channel from microchannel } \\
\text { to circular flow meter } \\
\text { - Measurement of two-phase flow } \\
\text { unknown }\end{array}$ \\
\hline Flow & Magnetic flow sensor (in-line) & $\begin{array}{l}\text { Measurement of flow } \\
\text { rate in parallel } \\
\text { refrigerant lines in } \\
\text { HX }\end{array}$ & 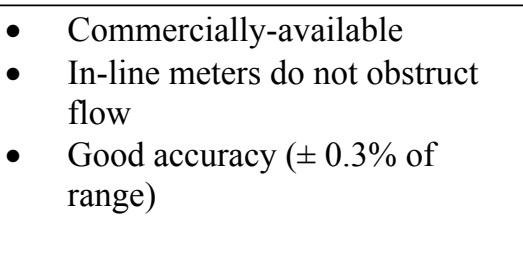 & $\begin{array}{ll}\text { - } & \text { Costly } \\
\text { - Intrusive, cannot easily transition } & \text { flow channel from microchannel } \\
\text { to circular flow meter } \\
\text { - Measurement of two-phase flow } \\
\text { unknown }\end{array}$ \\
\hline
\end{tabular}




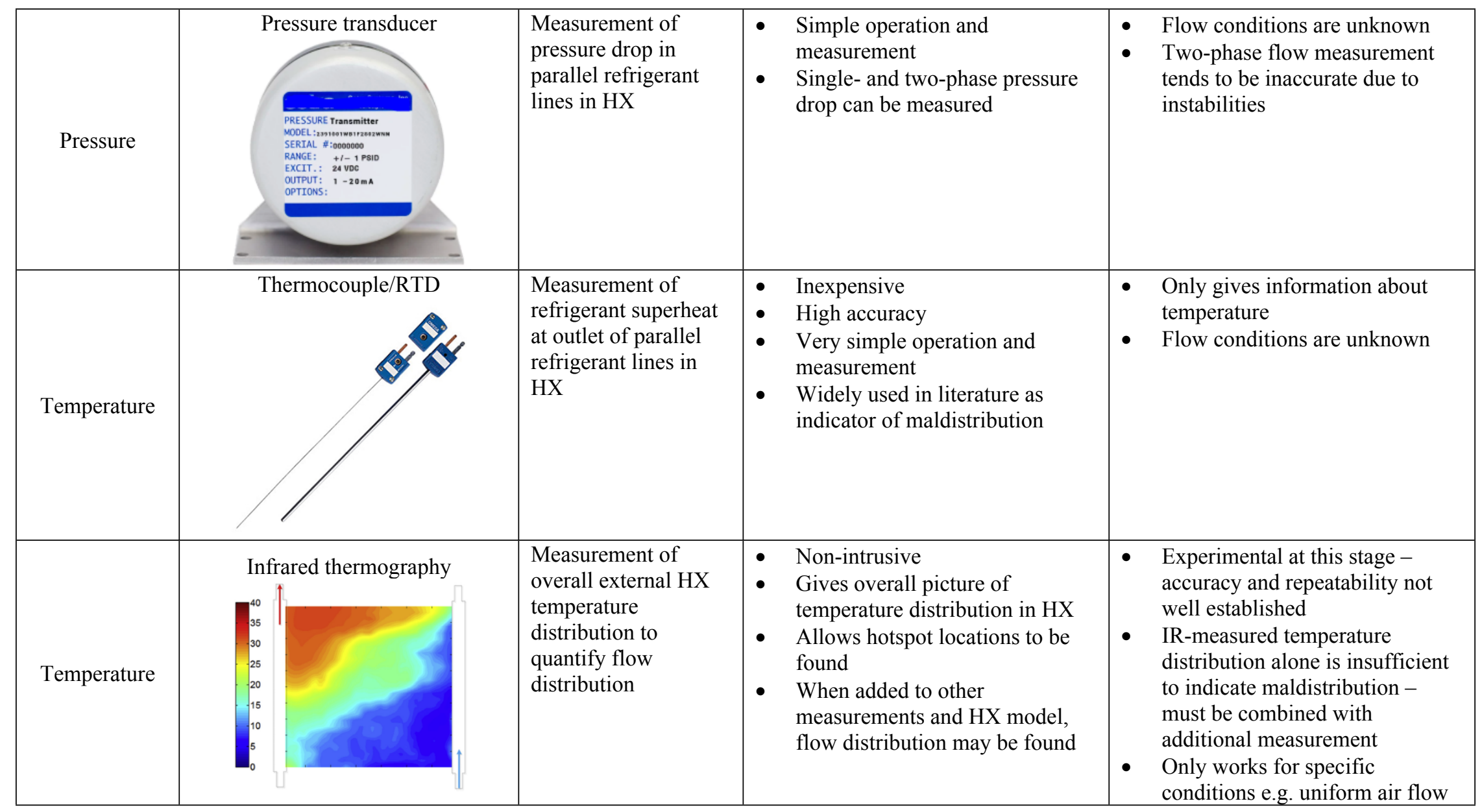

